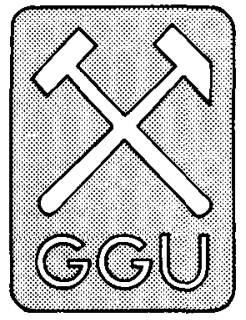

\title{
Project SUPRASYD 1992: opening season in the Ketilidian of South Greenland
}

\author{
Troels F. D. Nielsen, Brian Chadwick, Peter R. Dawes, \\ R. A. Frith and Hans K. Schønwandt
}

Project SUPRASYD was initiated in summer 1992 with a helicopter-supported field programme carried out between the end of June and mid-August. As outlined in last year's. Report of Activities (Dawes \& Schønwandt, 1992) the major aim of SUPRASYD is to provide an economic assessment of the Proterozoic Ketilidian mobile belt that forms the southern tip of Greenland (Fig. 1). In particular focus are supracrustal rocks and later intrusions.

The project, designed to run over several concurrent field seasons, includes a broad range of regional geological and structural studies, reconnaissance prospecting, mapping of specific targets as well as geochemical sampling. It is hoped that the multi-season effort will lead to a reappraisal of the mobile belt in terms of modern 'terrane models' allowing assessment of mineral potential in terms of primary environments and tectonic regimes.

The first year's field work, reported on here, was concentrated on the least-known region of the mobile belt - the south-eastern coast of Greenland - with a short visit to restricted localities on the south-western coast of Greenland at the end of the season.

\section{Logistic framework}

The south-eastern coast of Greenland is difficult of access. Offshoots of the Inland Ice dominate the high mountainous landscape, and outcrops are largely restricted to steep fjord walls. Previous geological work has been based on boat transport; the 1992 work with helicopter represents the first regional airborne geological survey of this part of Greenland. The Prins Christian Sund Telestation was used as a base-camp for the main operation; Nanortalik town was used as a base for the final days of the field work.

\section{Previous field work}

The Geological Survey of Greenland's (GGU) previous regional mapping of the Ketilidian mobile belt took place mainly during the late 1950 s and early 1960 s; the eastern part from Kap Farvel north to $62^{\circ} \mathrm{N}$ was visited in 1970.

The entire Ketilidian mobile belt is shown on the 1:500 000 map sheet, Sydgrønland, that was compiled in the early 1970s (Allaart, 1975). Regional descriptions, based essentially on the geology as portrayed on that map, are those of Allaart (1976) and the map description of the Sydgrønland map sheet by Kalsbeek et al. (1990). These sources demonstrate that our knowledge of the Ketilidian mobile belt is markedly heterogeneous. The western part (south-western coast) has been studied in detail (mainly mapped at 1:20000 and covered by published 1:100 000 maps) while the eastern part (south-eastern coast) is based on reconnaissance only. Pertinently, the geological knowledge of the south-eastern coast of Greenland at the start of project SUPRASYD rested heavily on a five-week boat reconnaissance in 1970, the aim of which was to complete the 1:500 000 Sydgrønland map sheet (Andrews et al., 1971). Sporadic observations were made in the extreme north-eastern part of the map sheet area in 1987 (Kalsbeek et al., 1990). Subsequent to the Survey's regional mapping, which was essentially concluded with the 1970 reconnaissance, geochemical work in the western part of the mobile belt has revealed a number of anomalies, e.g. gold (Steenfelt, 1990).

From the eastern part of the mobile belt Andrews and co-workers stressed the regional importance of quartzofeldspathic gneisses and acid volcanic material. Where best preserved "indubitable metamorphosed acid volcanics with primary phenocrysts and banding" crop out, and Andrews et al. $(1971$, p. 33) concluded that "the presence of recognisable acid volcanic units within all the major areas of gneiss visited gives us confidence in interpreting the gneiss sequence as essentially supracrustal in origin". In addition it was stressed that such supracrustal rocks and derived sequences are favourable hosts for sulphide mineralisation (Andrews et al., 1971, p. 37).

This tantalising description of the eastern part of the Ketilidian mobile belt was instrumental in directing the opening season of project SUPRASYD to the southeastern coast of Greenland; more specifically to the 
economic potential of the promising but cursorily known supracrustal sequences, and to the relationship of these rocks to the better-known rock units of the western part of the mobile belt.

\section{The 1992 programme}

The main field programme was carried out in the region between Prins Christian Sund $\left(60^{\circ} \mathrm{N}\right)$ and Mogens Heinesen Fjord $\left(62^{\circ} 15^{\prime} \mathrm{N}\right.$; Fig. 1). It was composed of two parts: (1) regional geological and prospecting reconnaissance (including chip and channel sampling of mineralised sequences), carried out by five geologists working mainly in teams of two and three; and (2) stream-sediment collecting for geochemical analysis that was accomplished by one geologist attached to the geological reconnaissance teams.

Two other activities were attached to the logistic framework of project SUPRASYD: (1) a regional gravity survey organised in collaboration with the Danish Kort- og Matrikelstyrelsen (KMS) including gravimetric measurements taken at the stream sediment sampling sites; and (2) a spot-check programme to assess satellite remote sensing images (the so-called GIRS project Geological Information from Remote Sensing).

This article deals mainly with the field results of the geological reconnaissance activity, with brief mention of anomalous results from assays of mineralised samples. The results of the stream sediment programme and those of the GIRS programme are presented by Steenfelt et al. (1992) and Tukiainen \& Erfurt (in press), respectively. The results of the gravity survey are available in a preliminary report (Thorning \& Hansen, 1993) and will be published jointly with KMS.

\section{Geological reconnaissance}

The main theme of the reconnaissance was the investigation of fundamental geological and chronological relationships, in particular definition and correlation of the previously described supracrustal and gneiss terrains. The geological survey aimed at covering the entire width of the mobile belt with a northern limit at around $62^{\circ} 15^{\prime} \mathrm{N}$. Previous work had placed the northern boundary with the Archaean block to be at the mouth of Mogens Heinesen Fjord immediately north of the island of Ikermit (Andrews et al., 1971, 1973; Pedersen et al., 1974).

The observations made in 1992 on the south-east coast of Greenland can be presented in terms of four principal areas, which in broad terms correlate with the four-fold subdivision of the mobile belt proposed by Allaart (1976). The four areas described below from north to south are: (1) Ikermit to Napasorsuaq Fjord; (2) Napasorsuaq Fjord to Kangerluluk; (3) Kangerluluk to Lindenow Fjord; (4) Lindenow Fjord to Prins Christian Sund. A fifth area visited, on the south-western coast of Greenland, is also described.

\section{Ikermit - Napasorsuaq Fjord area}

This area is composed of polyphase orthogneisses with enclaves of amphibolite that include metagabbro. The gneisses are cut by thick discordant sheets of medium- to fine-grained granite and more locally by bodies and dykes of mafic diorite that are regarded as part of an appinite association. The rocks in this zone are mostly in amphibolite facies and some of them show evidence of retrogression from possible granulite facies. The structures show predominantly N-S to NNE-SSW trending fabrics and resemble the structures described by Chadwick \& Walton (1988) from the region farther north $\left(62^{\circ} 30^{\prime} \mathrm{N}\right)$. Around Napasorsuaq Fjord there is a change in trend from dominantly $\mathrm{N}-\mathrm{S}$ to $\mathrm{E}-\mathrm{W}$ fabrics that coincides with a change in the regional aeromagnetic signature (Thorning, 1993). The structural change is taken to represent the increasing influence of Ketilidian tectonism (see later).

The orthogneisses are cut by ductile shear zones, mylonite zones and brittle fractures. Hornblende in veinlets, and localised ductile deformation in shear zones and belts of mylonite, indicate higher temperature conditions than the essentially brittle, low-grade deformation found in fracture systems north of the 1992 study area. Sub-horizontal sinistral displacements appear to be most common which points to transcurrent movement rather than overthrusting.

Undeformed, unmetamorphosed sedimentary rocks are preserved by down-faulting on isolated nunataks 50 km west of Otto Rud Øer (Fig. 1). These sediments, found in 1987 (Kalsbeek et al., 1990, p. 15), are up to several hundred metres thick and include cross-bedded sandstone, polymict conglomerate and mudstone. Locally disseminated azurite occurs in the matrix of the coarse-grained rocks. The sediments dip gently to the north and are cut by low-angle mafic sheets, dykes of granite and a body of granite in the west. They may be compared to sedimentary sequences discovered farther south around Danell Fjord, as well as those described farther west in the region around Tasermiut (Escher, 1966; Dawes, 1970) even though a stratigraphic correlation cannot be made. The sedimentary rocks are pre- 


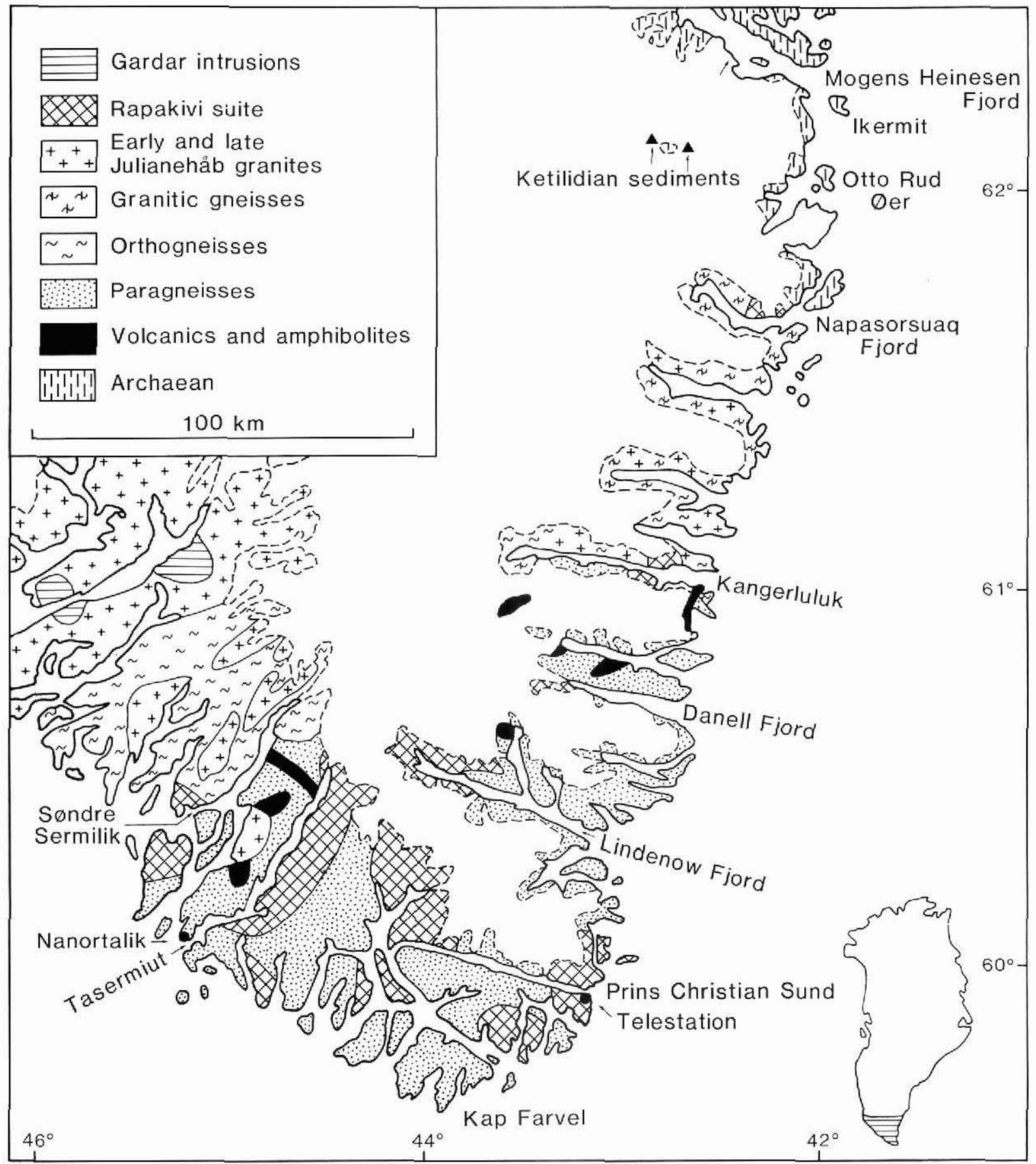

Fig. 1. Geological sketch map of the southern tip of Greenland.

sumed to overlie Archaean orthogneisses but the unconformity has not been seen.

The northern boundary of the Ketilidian mobile belt can be defined principally in terms of the northern extent of Proterozoic tectonism. The southern extent of the rocks thought to be Archaean is indicated on the geological sketch map (Fig. 1); the most northerly Proterozoic rocks are thought to be the unmetamorphosed sediments west of Otto Rud Øer noted above.

The northern boundary of Ketilidian tectonism is a broad transition zone north of Napasorsuaq Fjord. The zone occupies the area where the $\mathrm{N}-\mathrm{S}$ regional foliation 
trend in the Archaean rocks gives way southwards to E-W trending foliation.

\section{Napasorsuaq Fjord - Kangerluluk area}

The large area between Napasorsuaq Fjord and Kangerluluk was not investigated in any detail in 1992. In the north the main rock type is a variable gneissic, biotite granodiorite cut by net-veined diorite bodies and minor pegmatite. In the central part of the area, banded polyphase orthogneisses occur containing biotite and rare garnet, epidote, magnetite and tourmaline. The orthogneisses are cut by low-angle boudinaged amphibolite dykes and younger discordant sheets of steeply dipping granite. Massive, medium-grained, two-mica granite (s.l.) with a faint biotite foliation and abundant dioritic inclusions forms large parts of the area.

In the southern part of the area, heavily migmatised semi-pelitic and psammitic gneisses are common. These gneisses are intruded by granites, many of which are conspicuous concordant sheets having a fabric similar to their hosts, and by net-veined mafic diorite sheets. The diorite and granite sheets were deformed prior to the intrusion of basic dykes that are now foliated amphibolites.

\section{Kangerluluk - Lindenow Fjord area}

The area between Kangerluluk and Lindenow Fjord is mainly occupied by metasedimentary rocks with subordinate supracrustal amphibolites and younger granites. The general structure trends ENE-WSW with dips mainly to the NNW. Two main rock sequences can be recognised. Migmatised psammitic rocks dominate in the eastern part; a more mixed sequence of pelitic, semi-pelitic and psammitic rocks with amphibolites dominates in the west and structurally overlies the psammitic sequence.

The eastern psammitic sequence is variably migmatised with generally concordant coarse-grained neosome; locally anatexis is extreme. A few examples of cross-bedding were noted. The pelitic and semi-pelitic parts of the mixed sequence are intensely migmatised. Sulphide-bearing graphitic strata are common in the pelitic and semi-pelitic rocks, and their rusty appearance can be followed for many kilometres. The amphibolites show pillow structures testifying to their volcanic origin, but deformation has obliterated way-up criteria.

A major outcrop of metavolcanic rocks with interbedded semi-pelitic and psammitic units was found in the nunataks north-west of the head of Danell Fjord (Figs 1 $\& 2$ ). This sequence is more than $500 \mathrm{~m}$ thick and comprises basic to intermediate subaerial lavas and tuff with a few horizons of felsic volcanic and volcaniclastic rocks. The metavolcanics overlie a sequence of polymict conglomerates approximately $40 \mathrm{~m}$ thick, which has a lower contact with granite. However, the primary relationship between granite and the supracrustal sequence is ambiguous. A mafic dyke cutting the granite does not extend up into the conglomerate, a relationship suggesting a disconformity, whereas elsewhere apophyses of granite within the metavolcanics indicate an intrusive relationship.

\section{Lindenow Fjord - Prins Christian Sund area}

Heavily migmatised pelitic rocks with local psammitic intercalations dominate the area between Lindenow Fjord and Prins Christian Sund. Boudinaged amphibolite units and rare ultramafic rocks also occur. The foliation in the migmatites is commonly shallow, but areas of steep dips are present locally.

The migmatite neosome component includes thick concordant lenticular pegmatites. Locally the neosome is rich in garnet and cordierite. The heavily migmatised pelitic rocks show transitions into anatectic, schlieric, garnetiferous granites with a distinct foliation, concordant with the regional foliation of the migmatites. Large intrusions of the rapakivi suite occur in the area but were not examined in detail; most of the contacts appear to be concordant with foliation in the host gneisses and anatectic granites.

\section{South-western coast of Greenland}

A few days of helicopter reconnaissance organised from Nanortalik was made to the mountains between the head of Tasermiut and Søndre Sermilik fjords and north of Søndre Sermilik (Fig. 1). This afforded an opportunity to compare the metasedimentary rocks in the western part of the Ketilidian mobile belt with those investigated on the south-eastern coast of Greenland.

The metasedimentary rocks examined overlie grey granite which shows an intrusive contact with the metasedimentary rocks. The contact is mainly parallel to bedding. The metasedimentary sequence includes from bottom to top: pelitic schists, amphibolites with local agglomerates, psammites and polymict conglomerates. Amphibolites are subordinate to clastic sediments. The metasediments are in some areas steeply dipping, but towards the south-west there is a major area of subhorizontal psammites that is interpreted as the shallow limb of a large asymmetric syncline. The sequence resembles the metasedimentary rocks in the Kangerluluk - Lindenow Fjord area described above, although amphibolites dominate there. 


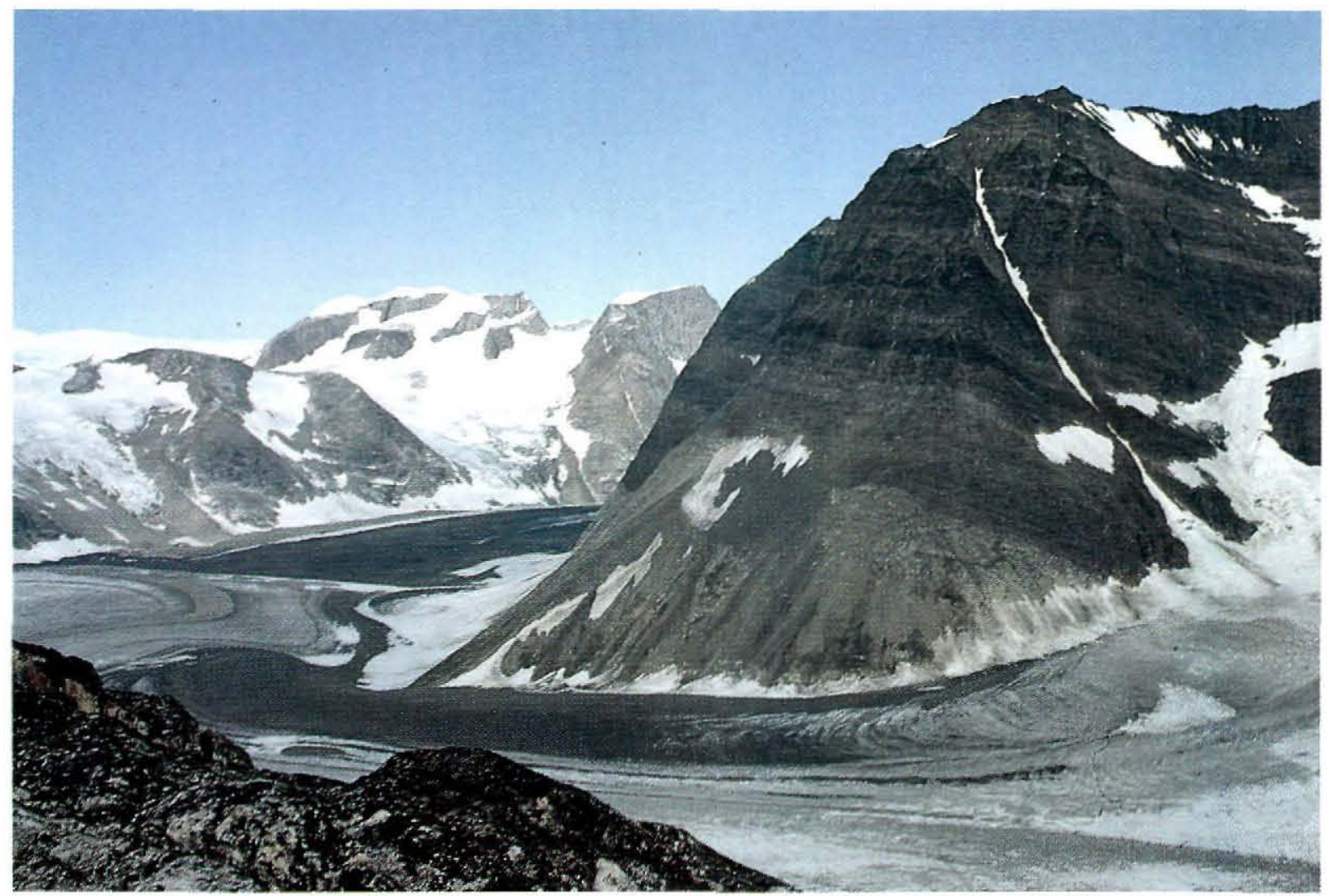

Fig. 2. Succession of slightly deformed Ketilidian sediments and volcanics at the head of Danell Fjord. Height of section about 700 m. Photo: R. A. Frith.

The granitic rocks examined to the north of the metasediments around Søndre Sermilik are variously deformed and locally resemble granitoid gneiss from the area north of Napasorsuaq Fjord. Intensely deformed mylonitic varietics occur immediately north of the metasediment contact. Mylonites with a wide range of orientation are prominent elsewhere in the granitic rocks close to the Inland Ice. Grey, foliated, medium-grained granites and darker dioritic and amphibolitic phases, commonly disrupted by pegmatites, seem to be a significant part of the granitic orthogneiss complex. Abundant mafic dykes occur in the granites and were emplaced at various stages during the syntectonic emplacement of granite,

Polyphase orthogneisses with agmatites occur locally and form a second group of gneisses in the area.

\section{Economic geology}

The 1992 field work indicates that the large area of Proterozoic supracrustal rocks south of Kangerluluk has promising possibilities for mineral deposits. The resemblance between the metasedimentary sequence in the
Tasermiut - Søndre Sermilik area, where recently goldbearing quartz veins have been found (Gowen et al. 1993), and those on the south-eastern coast of Greenland points to this area as an interesting gold exploration target. This is supported by analyses of two chalcocite-bearing, quartz-veined metavolcanic boulders collected in 1992 which yielded 1.6 and $2.6 \mathrm{ppm}$ gold. Sulphide-bearing, graphite-rich, cherty rust zones with a regional extent are also anomalous in gold. Analyses of chip samples yielded up to $188 \mathrm{ppb}$ gold.

The 1992 geochemical stream sediment survey (Steenfelt et al., 1992) supports the geological similarities noted between the supracrustal rocks in the western and eastern parts of the mobile belt; the anomalous gold province of the Tasermiut - Søndre Sermilik area has been found to continue eastwards. Gold and arsenic anomalies cluster around Lindenow Fjord and Danell Fjord in the central part of the supracrustal area, and the same general area also shows tungsten anomalies. The South-West Greenland uranium province has also been found to extend into the supracrustal area of the south-east coast with a maximum uranium value of the 1992 survey of stream sediments of $1400 \mathrm{ppm}$. 


\section{Conclusions}

One of the main conclusions of the 1992 geological reconnaissance must be that the geology as portrayed on the 1:500 000 map sheet, Sydgrønland (Allaart, 1975 ) is in need of extensive revision. This applies particularly to the eastern main study area of the SUPRASYD project, but also to the region visited to the west around Tasermiut and Søndre Sermilik. Many of the boundaries shown on the Sydgrønland map sheet were impossible to recognise in the field and rock types were misidentified by previous workers. Moreover it was not possible to confirm the interpretation (Andrews et al., 1971, 1973) that large areas of metamorphosed acid volcanic rocks outcrop, particularly in the northern region between Mogens Heinesen Fjord and Napasorsuaq Fjord.

Proterozoic supracrustal rocks in various stages of deformation and gneissification make up a substantial part of the Kangerluluk - Lindenow Fjord region. These supracrustal rocks are psammitic and semi-pelitic, not acid volcanics and volcanogenic sediments as previously deemed. Only relatively minor amounts of mafic volcanic rocks were encountered. Major new areas of supracrustal rocks were discovered in 1992, particularly in the region south of Kangerluluk. These, and the previously recorded sequences, await detailed study with respect to lithostratigraphy, sedimentology, basin development and structure. The possible correlatives in the Tasermiut - Søndre Sermilik area need to be incorporated into any assessment of the overall basinal setting of the rocks and judgement of the mineral potential.

In the western part of the Ketilidian mobile belt it was found that the Julianehaib granite complex (Allaart, 1976) probably extends as far south as Søndre Sermilik. The relationship between the granites of the complex and the polyphase migmatites occurring both inside and outside the complex should be established in order to throw light on the plutonic development of this part of the mobile belt.

Steep belts of mylonite within the Julianehåb granite complex require investigation in terms of kinematics and age. The significance of such investigations lies in the fact that a number of gold anomalies occur in the area north-west of Søndre Sermilik where several important shear zones have been identified.

Acknowledgements. The field work could not have been satisfactorily completed without the whole-hearted co-operation of the helicopter crews of Uni-fly A/S (chartered through Greenland Air A/S). Special thanks are due to the personnel at Prins
Christian Sund Telestation and the Telecenter Qaqortoq (Julianehåb) for generous hospitality.

\section{References}

Allaart, J. H. 1975: Geological map of Greenland 1:500 000 sheet 1 , Sydgrønland. Copenhagen: Grønlands Geologiske Undersøgelse.

Allaart, J. H. 1976: Ketilidian mobile belt in South Greenland. In Escher A. \& Watt, W. S. (ed.) Geology of Greenland, 121-151. Copenhagen: Geol. Surv. Greenland.

Andrews, J. R., Bridgwater, D., Gulson, B. \& Watterson, J. 1971: Reconnaissance mapping of South-East Greenland between $62^{\circ} 30^{\prime} \mathrm{N}$ and $60^{\circ} 30^{\prime} \mathrm{N}$. Rapp. Gronlands geol. Unders. 35, 32-38.

Andrews, J. R., Bridgwater, D., Gormsen, K., Gulson, B., Keto, L. \& Watterson, J. 1973: The Precambrian of SouthEast Greenland. In Park, R. G. \& Tarney, J. (ed.) The Early Precambrian of Scotland and related rocks of Greenland, 143-156. Birmingham University Press.

Chadwick, B. \& Walton, B. J. 1988: Preliminary report on the geology of the area between latitudes $62^{\circ} 30^{\prime}-63^{\circ} 00^{\prime}$ (Tingmiarmiut), Southeast Greenland. In Nielsen, T. F. D. (ed.) The Archean terrains in South-East Greenland, 3-16. Unpubl. intern. GGU rep.

Dawes, P. R. 1970: The plutonic history of the Tasiussaq area, South Greenland, with special reference to a high-grade gneiss complex. Bull. Grønlands geol. Unders. 88, 125 pp. (also Meddr Grønland 189,3).

Dawes, P. R. \& Schønwandt, H. K. 1992: Geological setting of Precambrian supracrustal belts: a fundamental part of mineral resource evaluation in Greenland. Rapp. Grønlands geol. Unders. 155, 19-23.

Escher, A. 1966: The deformation and granitisation of Ketilidian rocks in the Nanortalik area, S. Greenland. Bull. Grønlands geol. Unders. 88, 105 pp. (also Meddr Gronland 172,9).

Gowen, J., Christiansen, O., Grahl-Madsen, L., Robyn, T. \& Pedersen, J. 1993: Discovery of the Nalunaq gold deposit Kirkespirdalen, South-West Greenland. Abstract in Symposium Proceedings, Integrated methods in exploration and discovery, p. 6. Denver: Society of Economic Geologists.

Kalsbeek, F., Larsen, L. M. \& Bondam, J. 1990: Descriptive text to 1:500 000 sheet 1, Sydgrønland, $36 \mathrm{pp}$. Copenhagen: Grønlands Geologiske Unders øgelse.

Pedersen, S., Larsen, O., Bridgwater, D. \& Watterson, J. 1974: $\mathrm{Rb} / \mathrm{Sr}$ whole rock isochron age determinations on metamorphosed acid volcanic rocks and granitic gneisses from the Ketilidian mobile belt, South-East Greenland. Rapp. Gronlands geol. Unders. 66, 12-20.

Steenfelt, A. 1990: Gold content of regional stream sediment samples from South Greenland. Open File Ser. Grønlands geol. Unders. 90/5, $12 \mathrm{pp}$.

Steenfelt, A., Dam, E. \& Erfurt, P. 1992: Reconnaissance geochemical mapping of eastern South Greenland $\left(60^{\circ} 30^{\prime}\right.$ to $\left.62^{\circ} 30^{\prime} \mathrm{N}\right)$. Open File Ser. Grønlands geol. Unders. 92/10, 15 pp. 
Thorning, L. 1993: Preliminary aeromagnetic anomaly map (including 3 maps). In SUPRASYD 1992 field report, 6-9. Unpubl. intern. GGU rep.

Thorning, L. \& Hansen, E. 1993: Gravity measurements in South Greenland 1992 (including 9 maps). In SUPRASYD 1992 field report, 2-4. Unpubl. intern. GGU rep.

Tukiainen, T. \& Erfurt, P. in press: Application of SPOT and LANDSAT TM imageries to geological reconnaissance mapping, South Greenland. Open File Ser. Grønlands geol. Unders.
T. F. D. N., P. R. D. \& H. K. S., Geological Survey of Greenland, Copenhagen

B. C., Earth Resources Centre, University of Exeter, Exeter EX4 4QE, U.K.

R. A. F, Geological Survey of Canada, 601 Booth Street, Ottawa KIA OE8, Canada

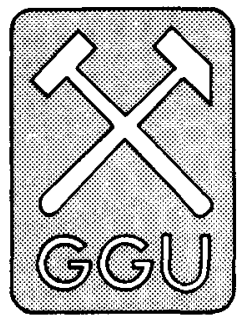

\section{Geochemical mapping and geological reconnaissance in the Nagssugtoqidian mobile belt, West Greenland}

\author{
Agnete Steenfelt, Feiko Kalsbeek \\ and Hans F. Jepsen
}

The Early Proterozoic Nagssugtoqidian mobile belt is geologically poorly known despite its location in the more populated part of West Greenland (Fig. 1). A detailed geological map (1:100 000; Olesen, 1984) is available for the western part of the Nordre Strømfjord area, but the remaining areas have only been mapped at 1:500 000 scale with geological reconnaissance along the coast and aerial photograph interpretation of inland areas (Map sheet 3: Søndre Strømfjord - Nûgssuaq; Escher, 1971).

The Nagssugtoqidian mobile belt has recently been interpreted as an area of continent-continent collision based on occurrences of Proterozoic calc-alkaline plutonic and volcanic rocks with isotope compositions reflecting a juvenile origin (Kalsbeek et al., 1987).

The re-interpretation of the Nagssugtoqidian belt from an ensialic (within-plate) feature to a suture zone between two Archaean crustal blocks changes the perception of the area's mineral potential. Existence of an early Proterozoic ocean and subduction zone would be favourable for the genesis of a number of ore deposit types, some of which might have survived later deformation and metamorphism. It is, therefore, important to look for further evidence to confirm or reject the collision model.

New geochemical data have been acquired and supplementary field observations made during GGU's reconnaissance geochemical mapping programme within the mobile belt. The programme, based on stream sediment and water sampling, covered the eastern part of the Nagssugtoqidian belt in 1990 and 1991 (Steenfelt \& Dam, 1991; Steenfelt et al., 1992), while most of the western part of the belt was sampled in 1992 (Steenfelt et al., 1993). The 1992 season also included geological field work at selected localities. In addition aeromagnetic data from parts of the mobile belt (Thorning, 1984) have recently been re-processed by $L$. Thorning to improve resolution. 